\title{
Oxidation processes and clogging in intermittent unsaturated infiltration
}

\author{
A. Bancolé, F. Brissaud and T. Gnagne \\ HYDROSCIENCES, MSE, Université Montpellier II, 34095 Montpellier Cedex 05, France \\ E.mail: brissaud@msem.univ-montp2.fr
}

\begin{abstract}
Intermittent infiltration of wastewater through non saturated sand bed is an extensive treatment process aimed at eliminating organic pollution, oxidizing ammonia and removing pathogens. A 1D numerical model, IPOX, has been worked out to simulate the transfer and oxidation of dissolved organic matter and nitrogen in unsaturated sand beds. IPOX was calibrated after real scale tests performed in Spain and Burkina Faso. Simulations allowed to point out the influence of (i) kinetics on oxidation performances and (ii) biomass development on the process sustainability. These results brought a new light on the sizing and operation of infiltration percolation and soil aquifer treatment (SAT) plants.
\end{abstract}

Keywords

Wastewater, intermittent infiltration, oxidation, clogging, numerical modeling

\section{INTRODUCTION}

Intermittent infiltration of wastewater through non saturated sand beds is an extensive treatment process aimed at eliminating organic pollution, oxidizing ammonia and removing pathogens. It has been widely applied for on site treatment and disposal of septic tank effluents, to treat primary effluents of small communities and polish secondary effluents of larger treatment plants before the reclaimed water is reused or disposed of in sensitive environments (Brissaud and Lesavre, 1993, Salgot et al., 1996). It has also been implemented in soil aquifer treatment (SAT) in the USA and Israel (Shelef and Azov, 1996).

Filtrating beds are constituted of sand, the mean grain size of which ranging between 200 and $800 \mu$ and the uniformity coefficient, $\mathrm{d}_{60} / \mathrm{d}_{10}$, being less than 10 . Large systems are divided into more than one field This allows alternated use of the individual fields and periodical drying of fields removed from service for a period of time, typically 2 to 3 days for the treatment of secondary effluents and one to two weeks for primary effluents. The organic deposit coating the bed surface is dried under sun exposure and wind effect. Thanks to endogenous respiration, drying periods also allow regulating the biomass accumulated in the porous medium, thus avoiding a possible clogging of the filter. Fields in operation are intermittently fed, flooding sequences alternating with drainage sequences, the daily number of feeding-drainage cycles, f, ranging between 1 and 20.

Sand beds behave as aerobic fixed biomass reactors, as far as the oxygen required to oxidize dissolved organic matter and nitrogen is available in the air phase of the porous medium. Oxygen is supplied to the air phase by exchanges with the atmosphere through the bed surface. Two mechanisms are involved in oxygen renewal: convection and molecular diffusion. When feeding 
sequences are short and the bed surface not long submerged after feeding, convective fresh air volumetric supply can be as high as the volume of water infiltrated - and drained - during a feedingdrainage cycle. Diffusive supply is function of the air porosity, the vertical distribution of oxidizable pollution and the time available for diffusive transfers. The diffusive contribution is important when hydraulic loads are less than $0.3 \mathrm{~m} \mathrm{~m}^{3} \mathrm{day}^{-1}$. Sizing guidelines were proposed for sand beds on the basis of a balance between oxygen needs and supply (Brissaud and Lesavre, 1993). Though they have proved to be useful, the theory behind these guidelines included too many assumptions to address two key issues : bed size optimisation and management of internal clogging. Particularly, dispersion, oxidation kinetics, biomass growth and its impact on the hydrodynamic characteristics of the sand bed were not taken into account. Therefore, it was necessary to consider a more comprehensive mathematical description of the mechanisms involved in the transfer of pollutants. The paper presents the numerical model IPOX, which, as in Tang et al., (1996), was derived from the HYDRUS code (Vogel et al., 1996). IPOX was calibrated after real scale tests performed in Spain and Burkina Faso. Then, it was used to investigate the effect of the main construction and operation parameters on oxidation performances and sustainability of infiltration percolation plants.

\section{IPOX MODEL}

The IPOX model calculates 1D unsteady water flow in unsaturated porous medium, dispersive transfer and the biological processes involved in the oxidation of dissolved organic matter and nitrogen biological oxidation.

Water flow is described by the Richards's equation

$$
\mathrm{C}(\mathrm{h}) \cdot[\partial \mathrm{h} / \partial \mathrm{t}]=\partial[\mathrm{K}(\mathrm{h}) \cdot\{\partial \mathrm{h} / \partial \mathrm{z}-1\}] / \partial \mathrm{z},
$$

were $\mathrm{h}$ is the pressure head, $\mathrm{C}$ the soil water capacity, $\mathrm{K}$ the hydraulic conductivity, $\mathrm{z}$ the positive downward depth and the time.

Porous media hydrodynamic characteristics, $K(h)$ and $\theta(h)$, with $\theta$ the volumetric water content are expressed through Van Guenuchten's functions:

$$
\theta(\mathrm{h})=\theta_{\mathrm{r}}+\left(\theta_{\mathrm{s}}-\theta_{\mathrm{r}}\right) /\left(1+|\boldsymbol{\alpha} \mathrm{h}|^{\mathrm{n}}\right)^{\mathrm{m}} \quad \text { and } \quad \mathrm{K}(\mathrm{h})=\mathrm{K}_{\mathrm{s}} \cdot \mathrm{S}_{\mathrm{e}}^{1 / 2}\left[1-\left(1-\mathrm{S}_{\mathrm{e}}{ }^{1 / \mathrm{m}}\right)^{\mathrm{m}}\right]^{2},
$$

with $\theta_{\mathrm{s}}$ and $\theta_{\mathrm{r}}$ the saturated and residual water contents respectively, $S_{\mathrm{e}}=\left(\theta-\theta_{\mathrm{r}}\right) /\left(\theta_{\mathrm{s}}-\theta_{\mathrm{r}}\right)$ the degree of saturation, $\mathrm{K}_{\mathrm{s}}$ the saturated hydraulic conductivity, $1 / \boldsymbol{\alpha}$ the threshold pressure head allowing air entrance in the porous medium, $\mathrm{m}=1-1 / \mathrm{n}$ and $\mathrm{n}$ a curve fitting parameter. The hydraulic conductivity varies with the microbial growth according to the following relationship

$$
\mathrm{K}_{\mathrm{s}}=\mathrm{K}_{\mathrm{so}}=\mathrm{a}\left(\theta_{\text {biof }}\right)^{\mathrm{b}}
$$

with $\mathrm{K}_{\mathrm{so}}$ the hydraulic conductivity in the absence of any biological development, $\theta_{\text {biof }}$ the water content corresponding to the biomass and $\mathrm{a}$ and $\mathrm{b}$ curve fitting parameters. $\theta_{\text {biof }}$ is calculated from the biomass content $\rho_{\text {biof }}: \theta_{\text {biof }}=\lambda \rho_{\text {biof }}, \lambda$ being the volume of the unit biomass.

The transport of solutes - dissolved organic matter, ammonium, and nitrate - is described taking into account that the liquid phase divides into mobile and immobile regions. Exchanges between mobile and immobile water are diffusive. Thus, the transfer of a non interactive tracer is described by the following equations:

$$
\partial\left(\mathrm{C}_{\mathrm{m}} \theta_{\mathrm{m}}\right) / \partial \mathrm{t}+\partial\left(\mathrm{C}_{\mathrm{im}} \theta_{\mathrm{im}}\right) / \partial \mathrm{t}=\partial\left[\mathrm{D}_{\mathrm{m}} \theta_{\mathrm{m}}\left(\partial \mathrm{C}_{\mathrm{m}} / \partial \mathrm{t}\right)-\mathrm{q} \mathrm{C}_{\mathrm{m}}\right] / \partial \mathrm{z} \quad \text { and } \quad \partial\left(\mathrm{C}_{\mathrm{im}} \theta_{\mathrm{im}}\right) / \partial \mathrm{t}=\alpha\left(\mathrm{C}_{\mathrm{m}}-\mathrm{C}_{\mathrm{im}}\right)
$$

with $C_{m}$ and $\theta_{m}, C_{i m}$ and $\theta_{i m}$, the tracer concentration and water content in the mobile and immobile regions respectively, $D_{m}=\varepsilon|q| / \theta_{m}+$ Do $\tau$ the longitudinal dispersion, $q$ the specific flow rate, $\varepsilon$ the 
dispersivity, Do the coefficient of molecular diffusion in a free liquid space, $\tau$ the tortuosity and $\alpha$ the exchange coefficient between the mobile and immobile regions. The mobile water content $\theta_{\mathrm{m}}$ is related to the water content $\theta$ by a linear relationship $\theta_{\mathrm{m}}=\mathbf{a} \theta_{\mathrm{s}} S_{\mathrm{e}}$, with $\mathbf{a}$ a constant.

The transfer of dissolved organic matter, which is represented by the chemical oxygen demand (COD) is governed by the following equations:

$$
\partial\left(\mathrm{C}_{\mathrm{m}, \mathrm{COD}} \boldsymbol{\theta}_{\mathrm{m}}\right) \partial \mathrm{t}+\partial\left(\mathrm{C}_{\mathrm{im}, \mathrm{COD}} \boldsymbol{\theta}_{\mathrm{im}}\right) / \partial \mathrm{t}=\partial\left[\mathrm{D}_{\mathrm{m}} \theta_{\mathrm{m}}\left(\partial \mathrm{C}_{\mathrm{m}, \mathrm{COD}} / \partial \mathrm{z}\right)-\mathrm{qC}, \mathrm{COD}\right] / \partial \mathrm{z}-\mathrm{P}_{\mathrm{COD}}
$$

and

$$
\partial\left(\mathrm{C}_{\mathrm{im}, \mathrm{COD}} \boldsymbol{\theta}_{\mathrm{im}}\right) / \partial \mathrm{t}=\alpha\left(\mathrm{C}_{\mathrm{m}, \mathrm{COD}}-\mathrm{C}_{\mathrm{im}, \mathrm{COD}}\right)-\mathrm{P}_{\mathrm{COD}}
$$

with $\mathrm{C}_{\mathrm{m}}, \mathrm{COD}$ and $\mathrm{C}_{\mathrm{im}, \mathrm{COD}}$ the $\mathrm{COD}$ in the mobile and immobile regions, $\mathrm{P}_{\mathrm{COD}}$ a sink term and $\boldsymbol{\theta}_{\text {im }}=\theta_{\text {im }}+\theta_{\text {biof }}$. Ammonium is irreversibly retained on the solid phase; its transfer from the mobile to the immobile region is described as proportional to the concentration in the mobile phase:

$$
\partial\left(\mathrm{C}_{\mathrm{m}, \mathrm{NH} 4} \theta_{\mathrm{m}}\right) \partial \mathrm{t}+\partial\left(\mathrm{C}_{\mathrm{im}, \mathrm{NH} 4} \boldsymbol{\theta}_{\mathrm{im}}\right) / \partial \mathrm{t}=\partial\left[\mathrm{D}_{\mathrm{m}} \theta_{\mathrm{m}}\left(\partial \mathrm{C}_{\mathrm{m}, \mathrm{NH} 4} / \partial \mathrm{z}\right)-\mathrm{qC}_{\mathrm{m}, \mathrm{NH} 4}\right] / \partial \mathrm{z}-\mathrm{P}_{\mathrm{NH} 4}
$$

and

$$
\partial\left(\mathrm{C}_{\mathrm{im}, \mathrm{NH} 4} \boldsymbol{\theta}_{\mathrm{im}}\right) / \partial \mathrm{t}=\alpha \mathrm{C}_{\mathrm{m}, \mathrm{NH} 4}-\mathrm{P}_{\mathrm{NH} 4}
$$

When $\theta_{\mathrm{im}, \mathrm{NH} 4} \mathrm{C}_{\mathrm{im}} \geq \mathrm{F}, \alpha=0$, with $\mathrm{F}$, the maximum $\mathrm{NH}_{4}$ retention capacity. The transport of nitrite and nitrate nitrogen, NOx, is defined by :

$$
\partial\left(\mathrm{C}_{\mathrm{m}, \mathrm{NOx}} \theta_{\mathrm{m}}\right) \partial \mathrm{t}+\partial\left(\mathrm{C}_{\mathrm{im}, \mathrm{NOx}} \boldsymbol{\theta}_{\mathrm{im}}\right) / \partial \mathrm{t}=\partial\left[\mathrm{D}_{\mathrm{m}} \theta_{\mathrm{m}}\left(\partial \mathrm{C}_{\mathrm{m}, \mathrm{NOx}} / \partial \mathrm{z}\right)-\mathrm{q} \mathrm{C}_{\mathrm{m}, \mathrm{NOx}}\right] / \partial \mathrm{z}-\mathrm{P}_{\mathrm{NOx}}
$$

and

$$
\partial\left(\mathrm{C}_{\mathrm{im}, \mathrm{NOx}} \boldsymbol{\theta}_{\mathrm{im}}\right) / \partial \mathrm{t}=\alpha\left(\mathrm{C}_{\mathrm{m}, \mathrm{NOx}}-\mathrm{C}_{\mathrm{im}, \mathrm{NOx}}\right)-\mathrm{P}_{\mathrm{NOx}}
$$

Oxygen transport in the air phase of the porous medium is represented by a conventional convection-dispersion equation (Refsgaard et al., 1991):

$$
\partial\left(\phi_{\mathrm{a}} \mathrm{C}_{\text {oxy }}\right) / \partial \mathrm{t}=\partial\left[\mathrm{D}\left(\partial \mathrm{C}_{\text {oxy }} / \partial \mathrm{z}\right)-\mathrm{q}_{\mathrm{air}} \mathrm{C}_{\text {oxy }}\right] / \partial \mathrm{z}-\mathrm{P}_{\text {oxy }}
$$

with $\mathrm{C}_{\text {oxy }}$, the oxygen content in the air phase, $\phi_{\mathrm{a}}$ the air porosity, $\mathrm{D}=\mathrm{AD}_{\mathrm{o}}\left(\phi_{\mathrm{a}}\right)^{\mathrm{B}}$ the oxygen diffusion coefficient, $D_{0}$ the oxygen diffusion coefficient in the air, $A$ and $B$ curve fitting parameters and $\mathrm{P}_{\text {oxyr }}$ a sink term which represents the oxygen uptake due to oxidation of organic matter and nitrogen.

Air and water flows are linked by two equations : $\phi_{\mathrm{a}}=\phi-\left(\theta_{\mathrm{m}}+\boldsymbol{\theta}_{\mathrm{im}}\right)$ with, $\phi$ the total porosity and $\partial \mathrm{q}_{\mathrm{air}} / \partial \mathrm{z} \approx-\partial \mathrm{q} / \partial \mathrm{z}$. Oxygen contents in the air phase, $\mathrm{C}_{\mathrm{oxy}}$, and the pore water, biofilm included, DO, are linked by Henry's law.

The biological degradation of organic matter and nitrogen oxidation take place in the biofilm. Substrate consumption, biomass growth, endogenous respiration and oxygen consumption are described by modified Monod's equation (Molz et al. 1986, Wood et al., 1994). Organic matter degradation, $\mathrm{P}_{\mathrm{COD}}$, is described by :

$$
\mathrm{P}_{\mathrm{COD}}=\left(\mu \mathrm{m}_{\mathrm{COD}} / \mathrm{Y}_{\mathrm{COD}}\right)\left[\mathrm{C}_{\mathrm{im}, \mathrm{COD}} /\left(\mathrm{K}_{\mathrm{COD}}+\mathrm{C}_{\mathrm{im}, \mathrm{DCO}}\right)\right]\left[\mathrm{DO} /\left(\mathrm{K}_{\mathrm{oxy}}+\mathrm{DO}\right)\right] \rho_{\text {biof,COD }}
$$

where $\mu \mathrm{m}_{\mathrm{COD}}$ is the maximum specific growth rate of heterotrophic biomass, $\mathrm{Y}_{\mathrm{COD}}$ the yield coefficient for $\mathrm{COD}, \mathrm{K}_{\mathrm{COD}}$ and $\mathrm{K}_{\mathrm{oxy}}$ the saturation coefficients for COD and oxygen respectively and $\rho_{\text {biof,COD }}$ the heterotrophic biomass content. Loss of ammonium through nitrification, $\mathrm{P}_{\mathrm{NH} 4}$, is defined by

$$
\mathrm{P}_{\mathrm{NH} 4}=\left(\mu \mathrm{m}_{\mathrm{NH} 4} / \mathrm{Y}_{\mathrm{NH} 4}\right)\left[\mathrm{C}_{\mathrm{im}, \mathrm{NH} 4} /\left(\mathrm{K}_{\mathrm{NH} 4}+\mathrm{C}_{\mathrm{im}, \mathrm{NH} 4}\right)\right]\left[\mathrm{DO} /\left(\mathrm{K}_{\mathrm{oxy}}+\mathrm{DO}\right)\right] \rho_{\text {biof,NH4 }}
$$

with $\mu \mathrm{m}_{\mathrm{NH} 4}$ is the maximum specific growth rate of autotrophic biomass, $\mathrm{Y}_{\mathrm{NH} 4}$ the yield coefficient for $\mathrm{NH}_{4}, \mathrm{~K}_{\mathrm{NH} 4}$ and $\mathrm{K}_{\text {oxy }}$ the saturation coefficients for $\mathrm{NH} 4$ and oxygen respectively and $\rho_{\text {biof,NH4 }}$ the autotrophic biomass content. 
Heterotrophic and autotrophic biofilms are modeled taking endogenous respiration into account (Horn and Hempel., 1997):

$$
\partial \rho_{\text {biof }} / \partial \mathrm{t}=\mathrm{Y}_{\mathrm{COD}} \mathrm{P}_{\mathrm{COD}}+\mathrm{Y}_{\mathrm{NH} 4} \mathrm{P}_{\mathrm{NH} 4}-\left(\mathrm{R}_{\mathrm{d}, \mathrm{COD}}+\mathrm{R}_{\mathrm{d}, \mathrm{NH} 4}\right)
$$

where $K_{d}\left[D O /\left(K_{\text {oxy }}+D O\right)\right] \rho_{\text {biof }}$ is the endogenous respiration and $K_{d}$ is a microbial decay rate. Maximum specific growth rates, $\mu_{\mathrm{m}}$, and decay rates $\mathrm{K}_{\mathrm{d}}$ depend on temperature according to Arrhenius's law.

The oxygen uptake is calculated as follows :

$$
\mathrm{P}_{\mathrm{oxy}}=\gamma_{\mathrm{COD}} \mathrm{P}_{\mathrm{COD}} \mathrm{Y}_{\mathrm{COD}}+\gamma_{\mathrm{NH} 4} \mathrm{P}_{\mathrm{NH} 4} \mathrm{Y}_{\mathrm{NH} 4}+\beta_{\mathrm{COD}} \mathrm{R}_{\mathrm{d}, \mathrm{COD}}+\beta_{\mathrm{NH} 4} \mathrm{R}_{\mathrm{d}, \mathrm{NH} 4}
$$

with $\gamma_{\mathrm{COD}}$ and $\gamma_{\mathrm{NH} 4}$ the oxygen use coefficients for heterotrophic and autotrophic synthesis and $\beta_{\mathrm{COD}}$ and $\beta_{\mathrm{NH} 4}$ the oxygen use coefficients for micro-organisms catabolism. Possible denitrification was not taken into consideration.

\section{MODEL CALIBRATION}

Hydrodynamic and dispersion parameters were derived from flow rate monitoring and tracer tests. Most parameter values describing biological processes are taken from the literature; others were calibrated after data from the monitoring of an infiltration percolation plant set in Mazagon (Andalusia-Spain). Primary effluent fed alternatively 3 pairs of $200 \mathrm{~m}^{2}$ basins and filtrated through unsaturated dune sands (Mottier et al., 2000). The daily hydraulic load was $0.25 \mathrm{~m}^{3} / \mathrm{m}^{2}$. Flow rates were monitored and percolating water was sampled at five depths ranging from 0.3 to $2.0 \mathrm{~m}$ during several feeding-drainage cycles. Samples were analyzed for COD, N-NH, $\mathrm{N}^{-\mathrm{NO}_{2}}$ and $\mathrm{N}-\mathrm{NO}_{3}$.

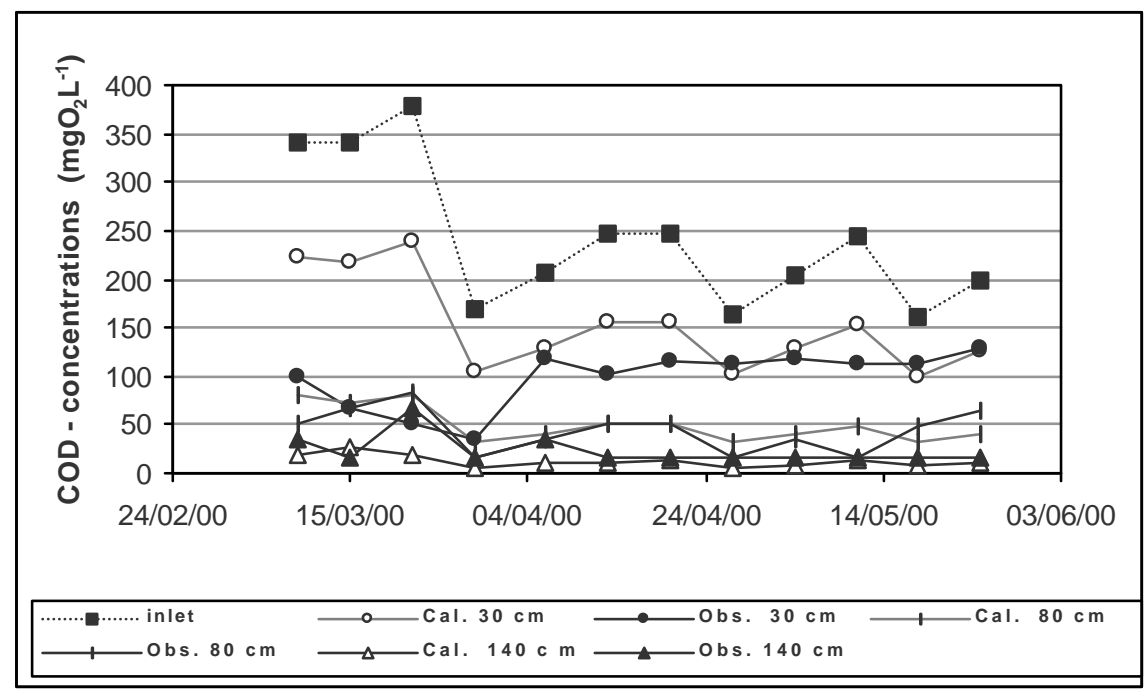

Figure 1: Observed and calculated COD at 30, 80 and $140 \mathrm{~cm}$ depths, in Kamboinsé treatment plant

In situ measurements of water content allowed evaluating $\theta_{\mathrm{s}}$ and $\theta_{\mathrm{r}}$. Other hydrodynamic parameters, $\mathrm{K}_{\mathrm{s}}, \mathrm{n}$ and $\boldsymbol{\alpha}$, were calibrated to fit the flow rate observed at $1.5 \mathrm{~m}$ depth during a feeding-drainage cycle. Flow rates observed at the other depths, together with water contents recorded between 5 and $50 \mathrm{~cm}$ below the surface, allowed a fair validation of the calibration, despite the unavoidable heterogeneity of field infiltration. Transport parameters $\mathrm{D}_{\mathrm{m}}$ and a were obtained from previous tests on sand columns. The exchange parameter between mobile and immobile waters, $\alpha$, which appeared to be greatly influenced by the biofilm, had to be calibrated together with the biologic parameters. Biologic parameters $\beta, \gamma, \mathrm{K}_{\mathrm{oxy}}$ and $\lambda$ were adopted from the literature while $\mu_{\mathrm{m}}, \mathrm{Y}, \mathrm{K}_{\mathrm{COD}}$ and $\mathrm{K}_{\mathrm{d}}$ were calibrated to fit $\mathrm{COD}, \mathrm{NH}_{4}$ and $\mathrm{NO}_{3}$ contents observed at 
0.3, 0.6, 1.5 and $2 \mathrm{~m}$ depths during a feeding-drainage cycle. Calibration values always felt within the range of literature values. The calibration was validated through the simulation of a second feeding-drainage cycle performed one week later.

The infiltration percolation plant of Kamboinse (Burkina Faso) treats 20 to $30 \mathrm{~m}^{3} / \mathrm{d}$ of septic tank effluent. The sand bed is $1.4 \mathrm{~m}$ deep. The mean grain size is $1.1 \mathrm{~mm}$ and the uniformity coefficient about 4 . The infiltration basin in operation is fed 2 or 3 times a day. Percolating water was sampled at $0.3,0.8$ and $1.4 \mathrm{~m}$ depths. Tracer tests performed on columns fed with the same sand allowed the calibration of hydrodynamic and dispersion parameters, $\theta_{\mathrm{s}}, \theta_{\mathrm{r}}, \mathrm{K}_{\mathrm{s}}, \mathrm{n}, \boldsymbol{\alpha}, \mathrm{Dm}$, a and $\alpha . \mathrm{COD}, \mathrm{NH}_{4}$ and $\mathrm{NO}_{3}$ transfers were simulated keeping the values of the biologic parameters taken from the literature or resulting of the calibration procedure in the Mazagon case. Temperatures in Burkina Faso do not significantly differ from those in June in Andalusia. Bearing in mind the heterogeneity of the water distribution on the bed surface, the simulation of pollution transfer and elimination was considered successful (Figure 1). This result was considered a supplementary validation of the model.

\section{OXIDATION PERFORMANCES AND INTERNAL CLOGGING}

Therefore the model could be used as a tool for a better understanding of the process, to assess the influence of construction and management parameters on pollution oxidation and internal clogging of sand beds and, eventually, to design infiltration percolation plants.

The construction parameters taken into consideration are the hydraulic load, $\mathrm{H}\left(\mathrm{m}^{3} \mathrm{~m}^{-2} \mathrm{~d}^{-1}\right)$, applied during the operation periods, the depth $L$ of the sand bed and the ratio of drying time to operation time. The management parameters are the daily number of feeding-drainage cycles, $\mathrm{f}$ (fractionation factor) and the operation-drying schedule.

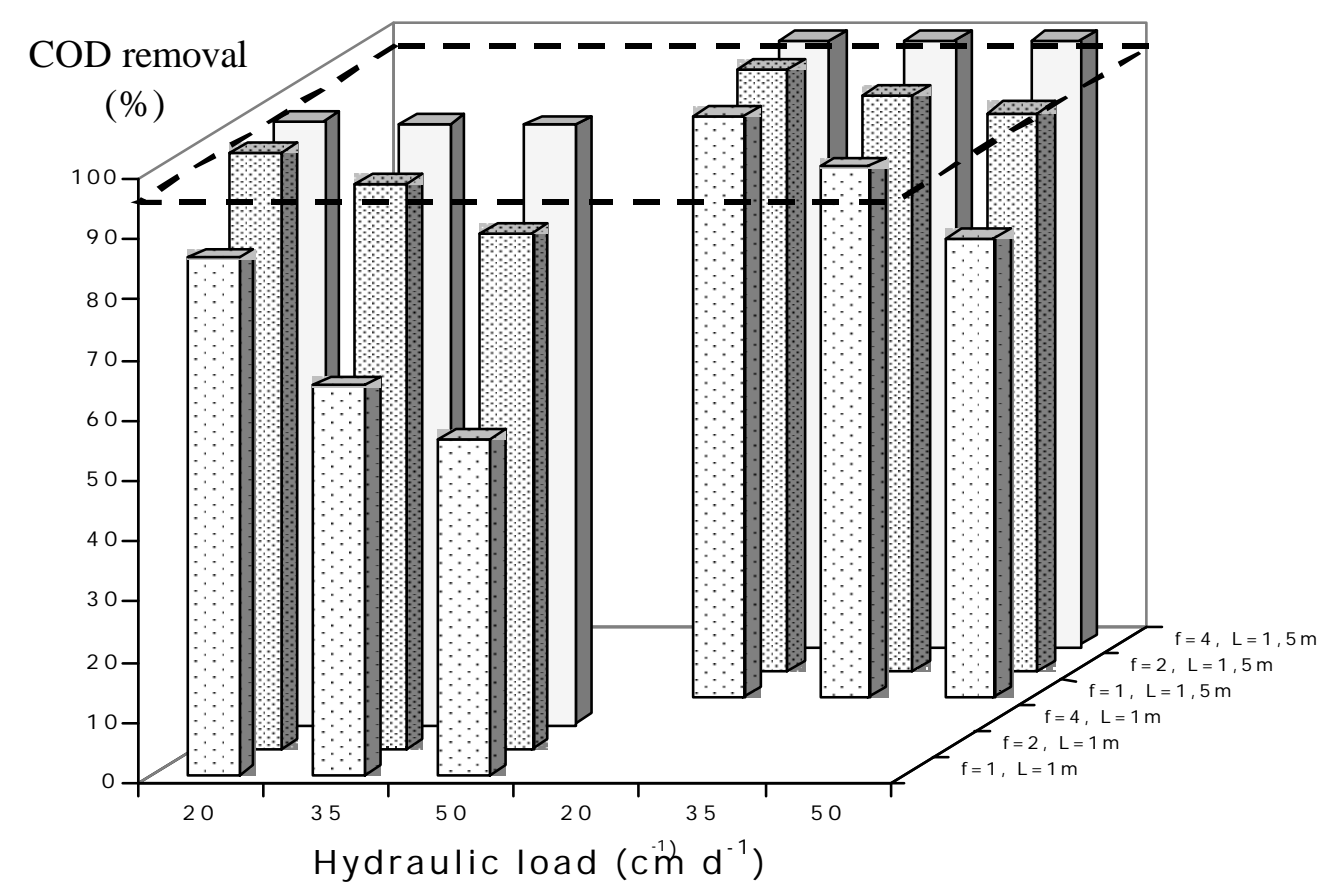

Figure 2. Influence of hydraulic load, fractionation and sand depth on COD removal

The infiltration percolation of primary treated effluent has been simulated for daily hydraulic loads of $0.2,0.35$ and $0.5 \mathrm{~m} / \mathrm{d}$, bed depths of $0.5,1.0$ and $1.5 \mathrm{~m}, 1,2,4$ and 8 feeding-drainage cycles per 
day and 0 to 4 days of drying per week. Primary effluent COD and ammonium nitrogen content were set at 300 and $60 \mathrm{mg} / \mathrm{L}$ respectively. The values of hydrodynamic, dispersion and biologic parameters were those obtained from the calibration procedure validated with the Kamboinse data; which means that the temperature is assumed to be as high as $24-25^{\circ} \mathrm{C}$ and biologic kinetics fast.

The elimination of COD and oxidation of nitrogen appeared to be highly dependent on both the bed depth and the fractionation of the daily load. For instance, for an hydraulic load of $0.5 \mathrm{~m} / \mathrm{d}$ and a bed depth of $0.5 \mathrm{~m}$, the average outlet COD was $189 \mathrm{mg} / \mathrm{L}$ for $\mathrm{f}=1$ and only $24 \mathrm{mg} / \mathrm{L}$ for $\mathrm{f}=8$. For the same load and a depth of $1 \mathrm{~m}$, the average outlet COD was 134, 44, 3 and zero $\mathrm{mg} / \mathrm{L}$ for $\mathrm{f}=1,2$, 4 and 8 respectively. It was demonstrated from tracer tests (Lefèvre, 1988, Brissaud et al., 1999) that the lower the $f$ and $L$ values, the shorter the water detention times for an increased part of the water flow. The achievement of complete oxidation requires a minimum water residence time. Simulations also showed that increasing the fractionation and the bed depth leads to higher oxidation of nitrogen. These results demonstrate the influence of oxidation kinetics on COD removal efficiency. COD removals are reported on Figure 2 as functions of hydraulic load, bed depth and fractionation. For a given target COD removal, the fractionation of the daily load allows to treat more water through reduced sand depth, thus saving investment costs (Figure 2).

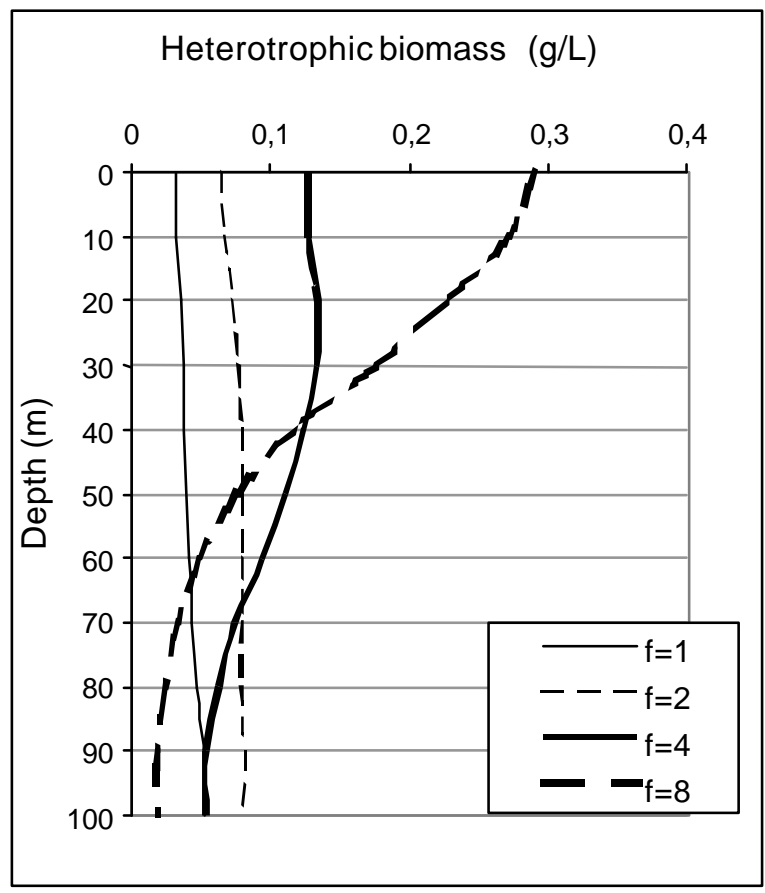

Figure 3. Heterotrophic biomass profile after 3 days operation $(\mathrm{H}=0.5 \mathrm{~m} / \mathrm{d}$; influent COD $=300 \mathrm{mg} / \mathrm{L}$; influent N-NH4 = $60 \mathrm{mg} / \mathrm{L}$ )

Increasing the fractionation of the daily load improves the filtered water quality but, in the same time, has a major adverse effect. After 3 days operation, when, for low f values; i.e. 1 and 2, the biofilm has evenly developped over the whole depth of the bed, it has accumulated in the upper layers of the sand bed at higher $\mathrm{f}$ values (Figure 3). This phenomenon is more pronounced for $\mathrm{f}=8$, with the main part of the biomass laying in the upper $30 \mathrm{~cm}$. It will become more and more important the following operation days. As the biomass increases, the hydraulic conductivity diminishes, reducing infiltration velocities and threatening the oxygen supply. No significant clogging appeared until 30 consecutive days of operation for $f=1$, while the bed surface long lasted flooded after 8.7 days for $\mathrm{f}=4$ and only 4.5 days for $\mathrm{f}=8$. Too high fractionation of the daily hydraulic threatens the process sustainability. 


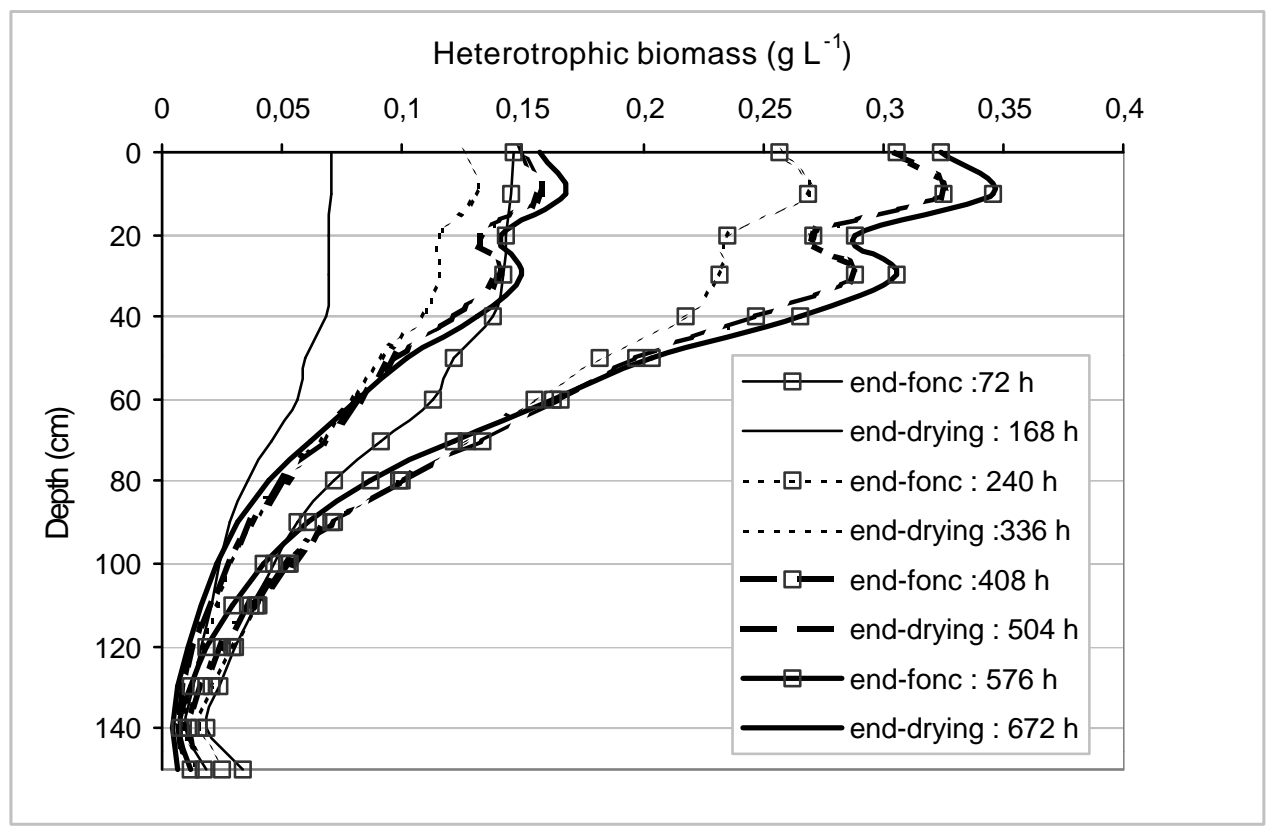

Figure 4. Biomass growth (operation periods) and decrease (drying periods) for a 3 days operating 4 days drying schedule. $\mathrm{H}=0.5 \mathrm{~m} / \mathrm{d}, \mathrm{f}=4$, influent COD and NTK $=300$ and $60 \mathrm{mg} / \mathrm{L}$ respectively.

Clogging is managed through alternation of operation and drying periods. During drying periods, endogenous respiration allows reducing the biomass, recovering the air porosity and, consequently, infiltration and oxidation capacities. However, as in the example of Figure 4, the ratio of drying time to operation time, $\mathrm{T}_{\mathrm{D}} / \mathrm{T}_{\mathrm{O}}$, may not be high enough to guarantee the sustainability of the process on the long term. Supplementary drying days must be allowed when necessary.

The ratio $\mathrm{T}_{\mathrm{D}} / \mathrm{T}_{\mathrm{O}}$, together with $\mathrm{H}$, determines the effective hydraulic load $\mathrm{H}^{*}$ and the surface $\Omega$ of the filter for a given daily flowrate $\mathrm{Q}$ :

$$
\Omega=\mathrm{Q}\left(1+\mathrm{T}_{\mathrm{D}} / \mathrm{T}_{\mathrm{O}}\right) / \mathrm{H}=\mathrm{Q} / \mathrm{H}^{*}
$$

Therefore the higher $\mathrm{H}^{*}$ the smaller the surface of the filter and the related costs. The model allowed to assess the duration at the end of which the bed surface becomes flooded due to internal clogging. This duration can be considered as a measure of the sustainability of the plant operation.

Table 1. Duration before first surface flooding ( $\mathrm{f}=4, L=1.5 \mathrm{~m}$, Influent COD and NK $=300$ and $60 \mathrm{mg} / \mathrm{L})$

\begin{tabular}{ccccccc}
\hline $\begin{array}{c}\text { Duration before } \\
\text { flooding }\end{array}$ & \multicolumn{2}{c}{$\mathrm{H}=0.5 \mathrm{~m} / \mathrm{d}$} & \multicolumn{2}{c}{$\mathrm{H}=0.35 \mathrm{~m} / \mathrm{d}$} & \multicolumn{2}{c}{$\mathrm{H}=0.2 \mathrm{~m} / \mathrm{d}$} \\
$\mathrm{T} / \mathrm{T}_{\mathrm{O}}$ & $\mathbf{H}^{*}(\mathbf{m} / \mathbf{d})$ & $\mathrm{T}_{\mathrm{D}} / \mathrm{T}_{\mathrm{O}}$ & $\mathbf{H}^{*}(\mathbf{m} / \mathbf{d})$ & $\mathrm{T}_{\mathrm{D}} / \mathrm{T}_{\mathrm{O}}$ & $\mathbf{H}^{*}(\mathbf{m} / \mathbf{d})$ \\
\hline 2 weeks & 0.61 & $\mathbf{0 . 3 1}$ & 0.28 & $\mathbf{0 . 2 7}$ & 0.11 & $\mathbf{0 . 1 9}$ \\
3 weeks & 0.88 & $\mathbf{0 . 2 6}$ & 0.52 & $\mathbf{0 . 2 3}$ & 0.28 & $\mathbf{0 . 1 6}$ \\
4 weeks & $\sim 1.16$ & $\mathbf{0 . 2 3}$ & 0.71 & $\mathbf{0 . 2 0}$ & 0.46 & $\mathbf{0 . 1 4}$ \\
\hline
\end{tabular}

It was shown that a given sustainability can be met through either applying high hydraulic load $\mathrm{H}$ with high $\mathrm{T}_{\mathrm{D}} / \mathrm{T}_{\mathrm{O}}$ value or low $\mathrm{H}$ and low $\mathrm{T}_{\mathrm{D}} / \mathrm{T}_{\mathrm{O}}$. However, higher $\mathrm{H}$ results in higher effective hydraulic load $\mathrm{H}^{*}$. The reason is that for high $\mathrm{H} / \mathrm{f}$ values, the biomass develops over the main part of the bed while it accumulates in the very upper layers for low $\mathrm{H} / \mathrm{f}$ values. Therefore, operationdrying schedules must be carefully chosen. 


\section{CONCLUSION}

The model allowed to demonstrate the influence of kinetics on the efficiency of intermittent infiltration and, as a consequence, on the sizing of sand filters. Bed depth and high fractionation of the daily hydraulic load improve the performances. But simulations pointed out the influence of the operation conditions on the biomass development and the related clogging risks, that are notably depending on load fractionation. The alternation of operation and drying periods must be defined together with the daily hydraulic load and the number of daily feeding-drainage cycles in order to minimize the volume of the sand bed, which represents the essential part of the construction costs. However, pollution oxidation seldom is the only objective of intermittent infiltration; removal of microorganisms is often at stake. The design and operation schedule of the plants should make careful compromises between the requirements of both the treatment goals and the process sustainability.

\section{ACKNOWLEDGEMENTS}

The authors wish to thank the French Ministry of Foreign Affairs for the support of this work trough the CAMPUS Program.

\section{REFERENCES}

Brissaud F. and Lesavre J. (1993). Infiltration percolation in France: 10 years experience. Wat. Sci. Tech. 28(10), 73-81.

Brissaud F., Salgot M., Bancolé A., Campos C. and Folch M. (1999). Residence time distribution and disinfection of secondary effluents by infiltration percolation. Wat. Sci. Tech. 40(4/5) :215-222.

Horn H. and Hempel D.C. (1997). Growth and decay in auto/heterotrophic biofilm. Wat. Res. 31(9), 2243-2252.

Lefevre F. (1988). Epuration des eaux usées urbaines par infiltration percolation. Etude expérimentale et définition de procédés. $\mathrm{PhD}$. thesis, Université Montpellier 2.

Molz F.J., Widdowson M.A. and Benefield L.D. (1986). Simulation of microbial growth dynamics coupled to nutrient and oxygen transport in porous media. Wat. Resour. Res. 22(8), 12071216.

Mottier V., Brissaud F., Nieto P. and Alamy Z. (2000). Wastewater treatment by infiltration percolation: a case study. Wat. Sci. Tech. 41(1), 77-84.

Refsgaard J.C., Christensen T.H. and Ammentorp H.C. (1991). A model for transport and consumption in the unsaturated zone. J. Hydrology 129, 349-369.

Salgot M., Brissaud F. and Campos C. (1996). Disinfection of secondary effluents by infiltration percolation. Wat. Sci. Tech. 33(10/11): 271-276.

Shelef G. and Azov Y. (1996). The coming era of intensive wastewater reuse in the Mediterranean region. Wat. Sci. Tech. 33(10/11), 115-125.

Tang. Z., Li G., Mays L.W. and Fox P. (1996). Development of methodology for the optimal operation of soil aquifeer treatment systems. Wat. Sci. Tech. 33(10/11), 433-442.

Vogel T., Huang K., Zhang R. and Van Genuchten M.Th. (1996). The hydrus code for simulating one-dimensional water flow, solute and heat movement in variably saturated media. Version 5.0. Research Report $n^{\circ}$ 140. U.S. Dep. of Agric. Riverside, California.

Wood B.D., Dawson C.N., Szecsody J.E. and Streile G.P. (1994). Modeling contaminant transport and biodegradation in a layered porous media. Water Resour. Res. 30(6), 1833-1845. 